\title{
Seismic Risk of Croatian Cities Based on Building's Vulnerability
}

\author{
Tanja KALMAN ŠIPOŠ, Marijana HADZIMA-NYARKO
}

\begin{abstract}
Seismic risk is fundamental for the establishment of priorities in long-term prevention policy since urbanization and concentration of population in earthquake prone areas are increasing. To assess seismic risk, it is necessary to determine seismic hazard and vulnerability for which large amount of input data is required. Therefore, a rapid seismic risk assessment is proposed, based on seismic hazard maps and on statistical Census data for buildings. A case study is illustrated for Croatian cities in order to provide an overview of the overall relative risk in Croatia. As a result, the prediction model for threatened buildings in Croatia in function of peak ground acceleration is proposed. The prediction model gives an indicative outcome after possible earthquake event expressed in terms of percentage of threatened buildings. Most vulnerable cities according to prediction model are Dubrovnik, Zagreb, Split and Rijeka in accordance with their buildings distribution by age.
\end{abstract}

Keywords: seismic risk assessment; seismic hazard; vulnerability of buildings; urban areas

\section{INTRODUCTION}

Determination of seismic risk for an area (or a particular building or infrastructure system) is an analytical method that integrates information, i.e. data and maps showing the general properties of the area, with the databases on the general properties and vulnerability values of the built environment. This is necessary in order to obtain an answer to the following questions: What may happen (economic losses, the number of casualties, the number of deaths, as well as losses of function - which may be expected due to tremors, rifting of soil, surface faulting)? Which probable consequences and losses may be expected for each possible outcome? Which unexpected circumstances may happen for each possible outcome?

Due to increasing urbanization and concentration of population in earthquake prone and earthquake vulnerable areas definition of seismic risk is mandatory. The seismic vulnerability of existing building stock is a fundamental task for establishment of priorities in a long-term prevention policy ([1-3]).

Seismic risk is probability of loss at a given site and is obtained through the convolution of seismic hazard, seismic vulnerability and exposure. Consequently, many sub-steps are involved: data collection, seismic hazard assessment, vulnerability assessment, determination of social and economic losses.

Vulnerability is defined as the degree of loss to a given element at risk resulting from a given level of hazard. Seismic hazard describes earthquakes or the effects of earthquakes (e.g., liquefaction, ground motion, etc.) and their frequency of occurrence. Exposure refers to the inventory of elements in a region where hazardous events may occur and it can be described as the value of the buildings and contents, lives, business interruption, the amount of human activity or other valuables that may lead to a potential loss in a seismic event [4].

There is no possibility to predict where and when the next destructive earthquake will happen, but awareness that the continuous growth of the population is related to a continuous growth of the size and number of towns and cities in seismic areas can lead to a reduction of potential catastrophic consequences. For this reason, the effort in reducing losses due to possible earthquakes is one of the key points in terms of risk evaluation.
Seismic risk and loss assessment in developed countries with a high incidence of earthquake activities are strictly defined. However, in Croatia seismic risk assessment is in its initial stage. This article complies with the regulations of the National Protection and Rescue Directorate of the Republic of Croatia [5], which state that it is necessary to conduct an analysis of the areas with high concentration of population, since the risk of major consequence of the effects of earthquakes will be most pronounced in such areas (metropolitan areas of major cities with surrounding settlements system, for example Zagreb, Osijek, Split, Rijeka).

In this paper, a rapid seismic risk assessment based on seismic hazard maps and on statistical Census data for dwellings are applied. This type of assessment is especially appropriate for developing countries, according to minimal number of input data for specific results [6].

The main result of the study is the prediction model for threatened buildings in Croatia in the function of peak ground acceleration.

\section{SEISMIC RISK ASSESSMENT METHODS}

In order to minimize potential damage of buildings as a consequence of earthquake event, appropriate urban prediction model is necessary. Accordingly, development of earthquake damage scenario using suitable infrastructure and building inventories, damage assessment criteria, topographical information, demographical data and other relevant facts must be defined.

Several state-of-the-art seismic risk assessments (Radius, Hazus, etc.), within many research studies involving large cities in the last few years (cities Barcelona-Spain [7], Athens-Greece [8], Quebec-Canada [9], Montreal-Canada [10], Byblos-Lebanon [11]) have been developed. All these approaches require a huge amount of various input data, which is impossible to collect in most of the developing countries. These approaches provided "detailed" seismic vulnerability assessments can be generally divided into three groups [12]: qualitative or empirical; quantitative or analytical and hybrid methods. Empirical methods for vulnerability assessments (such as Damage Probability Matrices (DPM), Vulnerability Index Method (VIM) and Screening Methods) are based on the observation of damage suffered during past seismic events 
and they have been implemented in many works ([1, 3, 7, 13, 14). Analytical methods (such as Analytically-Derived Vulnerability Curves and DPM, Collapse MechanismBased Methods, Capacity Spectrum-Based Methods) are used when a single building is evaluated in a detailed way and in numerical terms (for example, displacement capacity, ultimate force etc.) and can be found in many works ([15-20]).

Since seismic risk is growing worldwide along with growing urbanization it becomes, increasingly, a problem of developing countries, for which future earthquakes will have more disastrous social and economic consequences. Accordingly, it is necessary to develop, as an effective measure, a rapid assessment of seismic losses.

\subsection{Rapid Seismic Risk Assessment}

Seismic risk is the probability that humans will incur loss or damage to their built environment if they are exposed to a seismic hazard. In other words, seismic risk is an interaction between seismic hazard and vulnerability (humans or their built environment). In general, seismic risk can be expressed qualitatively as:

$$
R=H \cdot V
$$

As shown in Eq. (1), high seismic hazard $(H)$ does not necessarily mean high seismic risk $(R)$ and vice versa. There is no risk if there is no vulnerability $(V)$, expressed in terms of the number of inhabitants or number of populated buildings, even though there is a high seismic hazard.

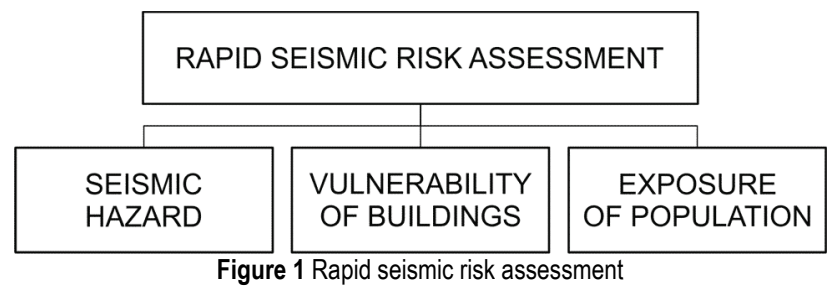

The concept of rapid seismic risk assessment, presented in Fig. 1, was developed and validated in accordance with real risk (number of threatened buildings and population) after the L'Aquila earthquake in Italy in 2009 [21]. According to the approved formulation, Eq. (2) will be used for calculation of buildings' vulnerability in Croatia:

$R_{\text {build }}=F_{\mathrm{H}} \cdot V_{\text {build }}$

where $R_{\text {build }}$ represents the risk regarding the building potential damage or percentage of number of threatened buildings, $V_{\text {build }}$ is the vulnerability of buildings which depends on their construction age, $F_{\mathrm{H}}$ is an impact factor that presents seismic hazard for the observed region or city.

\section{SEISMIC HAZARD FOR CROATIA}

Seismic hazard describes the probability that a given amount of the selected parameter that characterizes the observed ground motion at the site exceeds the reference period.
For Croatia, the hazard, presented with two maps, is expressed in terms of the peak horizontal ground acceleration during an earthquake, which is exceeded on average once in 95 or 475 years. The maps have been accepted as a part of the National Annex in HRN EN 1998$1: 2011$ [22]. In the map, which is used in designing earthquake resistant buildings, is shown the reference peak ground acceleration on type A for the return period of 475 years with a probability of exceedance of $10 \%$ in 50 years (Fig. 2). According to HRN EN 1998-1:2011 [22], soil type $A$ is defined as ground where the velocity of propagation of seismic waves exceeds $v>800 \mathrm{~m} / \mathrm{s}$ is composed of rock or other rock-like geological formations, including at most 5 meters of weaker material at the surface.

Possibility for earthquakes with peak ground acceleration of $0.3 \mathrm{~g}$ and higher is on an area of Croatian territory that is occupying $5.53 \%$ of the territory where about $21.02 \%$ residents live. The threat of earthquakes with peak ground acceleration of $0.2 \mathrm{~g}$ to $0.3 \mathrm{~g}$ covers $30.89 \%$ of the territory, where $41.66 \%$ residents live. On more than half of Croatian territory $(56.22 \%)$ there is the possibility for an earthquake with peak ground acceleration of $0.1 \mathrm{~g}$ to $0,2 \mathrm{~g}$, on which more than one-third (1.633.529) of the total Croatian population live.

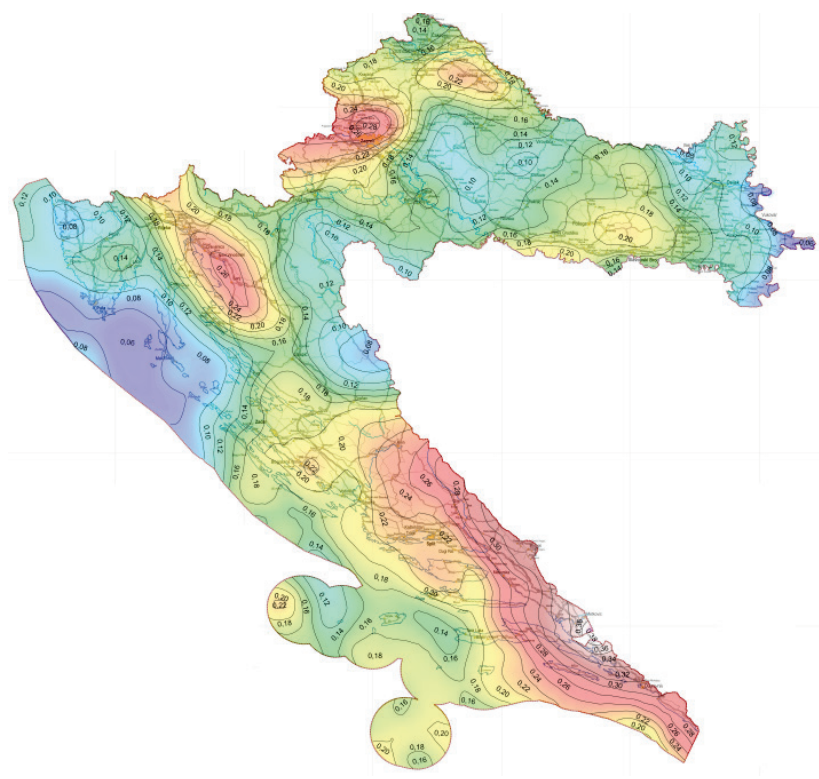

\footnotetext{
$\leq 0.1 \quad 0.10-0.14 \quad 0.14-0.18 \quad 0.18-0.22 \quad 0.22-0.26 \quad 0.26-0.36 \quad \geq 0.36$ Figure 2 Seismic hazard map for Croatia based on PGA in $\mathrm{g}\left(\mathrm{m} / \mathrm{s}^{2}\right)$ [23]
}

This map is used for determination of seismic risk in Croatia.

\section{VULNERABILITY OF BUILDINGS IN CROATIA}

To reduce the loss of human lives, buildings must be made safe. Laws governing construction in seismic zones today state that buildings must not be damaged by lowintensity earthquakes, must not be structurally damaged by medium-intensity earthquakes and must not collapse in the event of severe earthquakes despite suffering serious damage.

After an earthquake, to assess a building's vulnerability, it is enough to inspect the damage caused, associating it with the intensity of the tremor. 


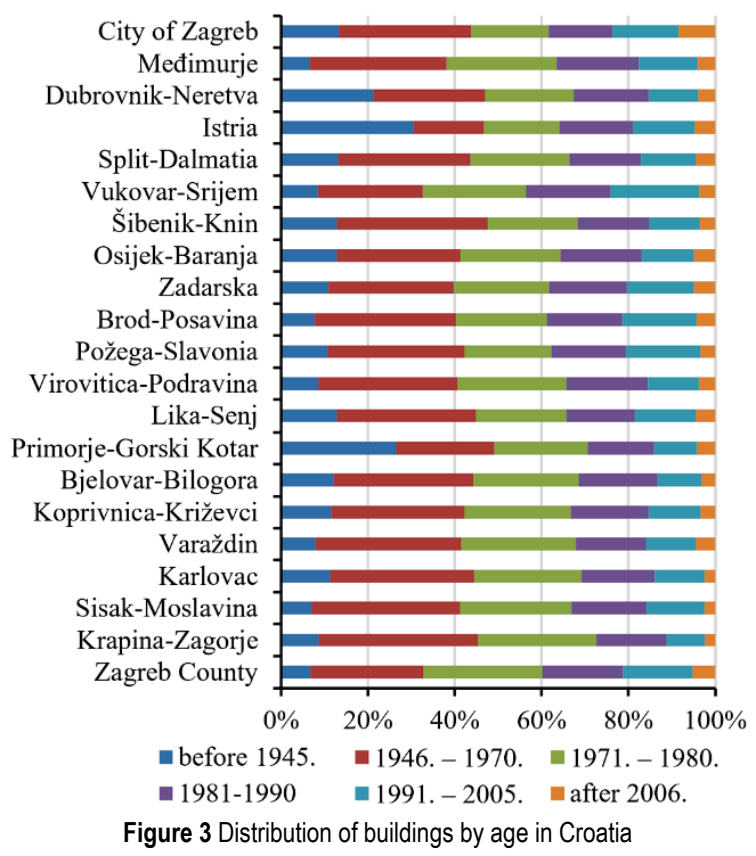

However, prediction of a building's vulnerability before a seismic event is quite complex, accordingly, statistical probability methods have to be applied in conjunction with expert opinions.

The construction age parameter for buildings allows capturing the conditions of design standards as well as the requirements of the building codes, thus presents a factor that is directly related to the vulnerability [24]. According to the previous statement, the distribution of buildings in Croatia was done according to their construction age. Classification was made by six groups according to associated seismic regulation and type of construction. In Fig. 3, percentage of buildings within certain construction age and County is presented. The results show that the most of the buildings were built in 1945-1980 (30\% between 1946 and 1970, and 23\% between 1971 and 1980).

The construction practices and building stock characteristics in a region may change overtime but some main characteristics and similarity of construction, materials and quality of construction for each construction period are the same and conclusions about their seismic behaviour and resistance can be made for specific type of structures not only for one city, but for all of the cities in Croatia.

Masonry buildings until 1920 had the floor structure entirely of wood. Buildings that are currently part of old city cores of Croatia were, in most cases, built between 1860 and 1920. Such buildings can be considered as built heritage, in case any intervention is to be undertaken on these buildings. These buildings were not designed to cope with strong horizontal motions (earthquake) [25].

From 1945-1964, monolithic reinforced concrete floors were predominantly used. After 1964, masonry buildings were systematically built with horizontal tiebeams and vertical tie-columns to provide confined masonry buildings [5].

Also, residential buildings with reinforced concrete bearing system have been built under the provisions of seismic regulations from 1964 (after the earthquake in Skopje) and 1981 [26] (after the earthquake on the Montenegro coast), and can be considered as modern method of construction in terms of the scientific (seismic, geotechnical, geomechanical etc.) knowledge of this period.

Between 1992 and 1998, all Eurocodes for structural design were introduced, but due to difficulties of harmonization with national legislation, they maintained a prestandards status (ENV label). Finally, in 1998, the second and final version was issued, with the full European standard label (EN label), and accompanying instructions for its application.

The final implementation of Eurocode in Croatia started in 2005, by the issuance of the Technical Regulations for Concrete Structures (NN 101/05) [27] with amendments and modification in 2006 and 2007. In 2009, these regulations were completely replaced (NN 139/2009) [28], and have already been amended and revised in 2010.

Table 1 Classification of buildings by construction age, with appurtenant type of construction and seismic regulations for Croatia

\begin{tabular}{|c|c|c|c|c|c|c|c|}
\hline \multicolumn{2}{|c|}{ Building's factors } & $F_{\text {build, } 1}{ }^{1}$ & $F_{\text {build,2 }}$ & $F_{\text {build,3 }}$ & $F_{\text {build,4 }}$ & $F_{\text {build,5 }}$ & $F_{\text {build,6 }}$ \\
\hline \multicolumn{2}{|c|}{ Common type of construction } & $\begin{array}{l}\text { Stone masonry } \\
\text { buildings with } \\
\text { wooden slabs }\end{array}$ & $\begin{array}{l}\text { Brick masonry } \\
\text { with RC slabs }\end{array}$ & $\begin{array}{l}\text { Masonry with RC } \\
\text { slabs, pre-code RC } \\
\text { frames }\end{array}$ & \multicolumn{3}{|c|}{$\mathrm{RC}$ buildings, confined masonry buildings } \\
\hline \multicolumn{2}{|c|}{ Seismic regulation (design standards) } & - & - & $\begin{array}{c}1^{\text {st earthquake design }} \\
\text { regulation }\end{array}$ & $\begin{array}{c}\text { Regulation } \\
1981[26] \\
\end{array}$ & $\begin{array}{l}\text { Prestandards } \\
\text { (ENV) }\end{array}$ & $\begin{array}{c}\text { Eurocode } 8 \\
{[22]}\end{array}$ \\
\hline \multicolumn{2}{|c|}{ Age distribution } & before 1945 & $1946-1970$ & $1971-1980$ & $1981-1990$ & $1991-2005$ & After 2006 \\
\hline Number of dwellings & $\Sigma=1470110$ & 197180 & 427421 & 325203 & 247084 & 200150 & 73072 \\
\hline
\end{tabular}

Most of the buildings built in the last decade are in accordance with Eurocode 8 provisions for earthquakeresistant design (only $4 \%$ of all buildings). However, a great number of older low- and medium-rise buildings are built from stone and masonry blocks, not following any of such provisions (Tab. 1). These buildings must be evaluated and their level of vulnerability and risk determined.

\section{RAPID SEISMIC RISK ASSESSMENT APPLICATION}

Application of RAPID assessment is based on direct determination of participating factors: impact factor for seismic hazard and vulnerability of buildings based on construction age.

\subsection{Determination of Seismic Hazard Impact Factor}

From the map presented in Fig. 2, the peak ground acceleration value was obtained for 429 municipalities and 127 cities in Croatia. These data were used for 
determination of the seismic hazard factor $F_{\mathrm{H}}$. The data were summarised and distribution of data was determined by frequency and correlation between values by a cumulative log-normal function shown in Fig. 4.

The lognormal distribution function has been the most common form used in the derivation of fragility curves and seismic risk [29].

The lognormal cumulative distribution function presented in Eq. (3) is expressed using two parameters $\mu$ and $\sigma . \mu$ is the scale parameter and $\sigma$ is the shape parameter, which corresponds to the mean and standard deviation of the normally distributed natural logarithm of $t$.

$F(x \mid \mu, \sigma)=\frac{1}{\sigma \sqrt{2 \pi}} \int_{0}^{x} \frac{\mathrm{e}^{-\frac{[\ln (t)-\mu]^{2}}{2 \sigma^{2}}}}{t} \mathrm{~d} t$

Seismic hazard impact factor $F_{\mathrm{H}}$ is essentially a distribution that defines the probability non-exceeding a specific $P G A$ value and can easily be calculated according to Eq. (3) with lognormal function parameters from Tab. 2. This cumulative lognormal function for $F_{\mathrm{H}}$ is presented in Fig. 4.

\subsection{Determination of Building's Vulnerability Impact Factors}

Statistical methods classify buildings according to their construction materials and techniques, based on damage observed in previous earthquakes to the same kind of buildings. This technique requires damage data from past earthquakes, which is not always available, and cannot be used to assess the vulnerability of individual buildings, because it is statistical in nature and not specific.

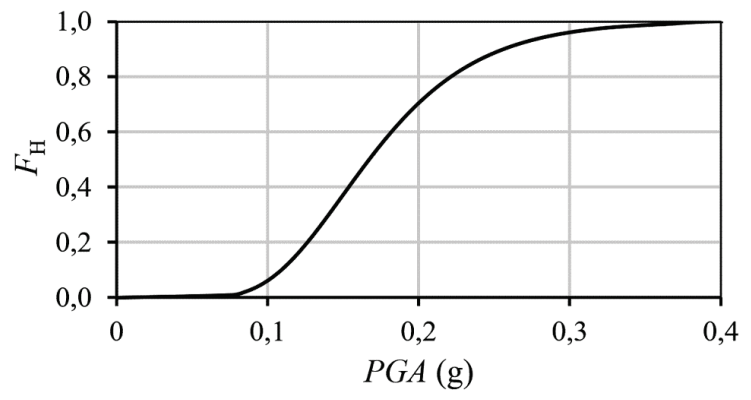

Figure 4 Seismic hazard impact factor $F_{\mathrm{H}}$ for Croatia

Mechanistic methods, however, use theory, not statistical models, for assessing the damage of buildings caused by simulated earthquakes. Finally, in order to assess the vulnerability of buildings throughout Croatia, statistical methods were used with capturing standard data regarding their characteristics. Census data regarding dwellings are available for every county in Croatia and it was used in the application of rapid assessment method.

Accordingly, the building vulnerability is defined by construction age and by six divisions for certain period of time, as is presented in Tab. 1. For every age distribution, dwelling's data were collected from Census data [6] and processed to obtain cumulative lognormal function parameters, mean and standard deviation. As a result, building's factors $F_{\text {build } i}(i=1, \ldots, 6)$ were defined (Tab. 2 ). In this paper, vulnerability of buildings is derived from vulnerability of dwellings as part of buildings from Census data according to results presented in percent.

Table 2 Parameters of cumulative lognormal functions for impact factors

\begin{tabular}{|l|c|c|}
\hline \multicolumn{1}{|c|}{ Factor } & $\mu$ - mean & $\sigma$-standard deviation \\
\hline$F_{\mathrm{H}}$ & -1.788 & 0.334 \\
\hline$F_{\text {build, } 1}$ & 4.821 & 1.109 \\
\hline$F_{\text {build,2 }}$ & 5.608 & 1.137 \\
\hline$F_{\text {build,3 }}$ & 5.357 & 1.117 \\
\hline$F_{\text {build,4 }}$ & 5.139 & 1.045 \\
\hline$F_{\text {build,5 }}$ & 4.828 & 1.148 \\
\hline$F_{\text {build,6 }}$ & 3.434 & 1.276 \\
\hline
\end{tabular}

In order to calculate the vulnerability of buildings according to the proposed RAPID assessment procedure [21], every building's factor $F_{\text {build,i }}$ must be multiplied with a weight factor $w_{i}$ corresponding to possible damage after the earthquake (Eq. (4)):

$V_{\text {build }}=\sum_{i=1}^{6} w_{\mathrm{i}} \cdot F_{\text {build, } \mathrm{i}}$

These contributions of weights were defined according to Pairwise Comparison Method (PCM). This method quantifies the relative importance of different factors, for example, buildings, with respect to their construction age, increase vulnerability 4 times more if they are built before 1945.

The PCM method converts the comparisons of all pairs of factors to quantitative weights under the matrix containing the pairwise comparison judgments for certain criteria (age of buildings for vulnerability of buildings). The PCM method with geometric mean method was used for several reasons: it synthesizes the multitude of factors involved in the process, is based on reciprocal axiom, homogeneity axiom and independency of judgment at each level [30].

The comparisons are being made between pairs of subindicators where perception is sensitive enough to make a distinction. The most important aids were prevailing percent of buildings for certain vulnerability class from Tab. 1. Accordingly six age groups of buildings are based on their construction age. Their comparisons resulted in values of sub-indicators for weights calculation: for scale from 1 to 4 it means that buildings (dwellings) with factor 1 (older buildings from stone masonry buildings with wooden slabs $-w_{1}$ ) have 4 times higher possibility for vulnerability in regard to buildings built after $2006\left(w_{6}\right)$. Respectively, buildings which were built between 1946 and $1970\left(w_{2}\right)$ will have 2 times higher possibility, etc. Accordingly, the same vulnerability class indicated similarity in possible behaviour which resulted in small change in sub-indicators preferences ( $w_{4}$ to $w_{5}$ to $w_{6}$ ).

In the PCM geometric mean method, the entire elements in the row of the pairwise comparison matrix are multiplied and their root is taken where $n$ is the number of factors ( $n=6$ in this study). The weights $w_{i}$ are then normalised dividing row multiplied values $\mathrm{RMV}^{(1 / n)}$ values by their sum (Tab. 3). 
Table 3 Calculation of weights $w_{\mathrm{i}}$ according to PCM geometric mean method

\begin{tabular}{|c|c|c|c|c|c|c|c|c|c|}
\hline & $w_{1}$ & $w_{2}$ & $w_{3}$ & $w_{4}$ & $w_{5}$ & $w_{6}$ & $\mathrm{RMV}^{1}$ & RMV $^{(1 / n)}$ & ${\text { normalized value of } w_{i}}$ \\
\hline$w_{1}$ & 1.00 & 2.00 & 3.00 & 3.30 & 3.70 & 4.00 & 293.04 & 2.58 & 0.376 \\
\hline$w_{2}$ & 0.50 & 1.00 & 1.50 & 1.65 & 1.85 & 2.00 & 4.58 & 1.29 \\
\hline$w_{3}$ & 0.33 & 0.67 & 1.00 & 1.10 & 1.23 & 1.33 & 0.40 & 0.86 & 0.188 \\
\hline$w_{4}$ & 0.30 & 0.61 & 0.91 & 1.00 & 1.12 & 1.21 & 0.23 & 0.78 & 0.125 \\
\hline$w_{5}$ & 0.27 & 0.54 & 0.81 & 0.89 & 1.00 & 1.08 & 0.11 & 0.114 & 0.102 \\
\hline$w_{6}$ & 0.25 & 0.50 & 0.75 & 0.83 & 0.93 & 1.00 & 0.07 & 0.64 & \\
\hline
\end{tabular}

row multiplied value

Table 4 Calculation of seismic risk for Zagreb according to RAPID assessment

\begin{tabular}{|c|c|c|c|c|c|c|c|c|}
\hline & \multicolumn{4}{|c|}{ Buildings } & \multicolumn{2}{|c|}{ Hazard } & \multicolumn{2}{|c|}{ Risk } \\
\hline Construction age & $\begin{array}{c}\text { Number of } \\
\text { dwellings } \\
\text { (Census data) }\end{array}$ & $\begin{array}{c}F_{\text {build, } i} \\
\text { (Eq. (3) and Tab. 2) }\end{array}$ & $\begin{array}{c}w_{i} \\
\text { (Tab. 3) }\end{array}$ & $\begin{array}{c}V_{\text {build }} \\
\text { (Eq. (4)) }\end{array}$ & $\begin{array}{l}\text { PGA (g) } \\
\text { (Fig. 2) }\end{array}$ & $\begin{array}{c}F_{\mathrm{H}} \\
\text { (Fig. } 4 \text { and Tab. 2) }\end{array}$ & $R$ (Eq. (2)) & $\begin{array}{c}\% \text { of threatened } \\
\text { buildings }\end{array}$ \\
\hline before 1945 & 11518 & 0.999 & 0.376 & \multirow{6}{*}{1.0} & \multirow{6}{*}{0.26} & \multirow{6}{*}{0.902} & \multirow{6}{*}{0.902} & \multirow{6}{*}{90.2} \\
\hline $1946-1970$ & 27948 & 0.999 & 0.188 & & & & & \\
\hline 1971-1980 & 90233 & 1 & 0.125 & & & & & \\
\hline 1981-1990 & 53028 & 1 & 0.114 & & & & & \\
\hline 1991-2005 & 71649 & 1 & 0.102 & & & & & \\
\hline After 2006 & 42556 & 1 & 0.094 & & & & & \\
\hline
\end{tabular}

\subsection{Derivation of Seismic Risk for Croatia}

According to Eq. (2), $R_{\text {build }}$ is calculated for every city in Croatia and then presented in Fig. 5.

An example calculation of risk is made for capital city of Zagreb (Tab.4). The number of dwellings according to construction age is obtained from Census data (Croatian bureau of statistics, 2011). Impact factors $F_{\text {build,I }}$ for every construction age are derived from cumulative lognormal functions parameters presented in Tab. 2 and then multiplied with relative weights (Tab. 3) for each factor according to Eq. (4).

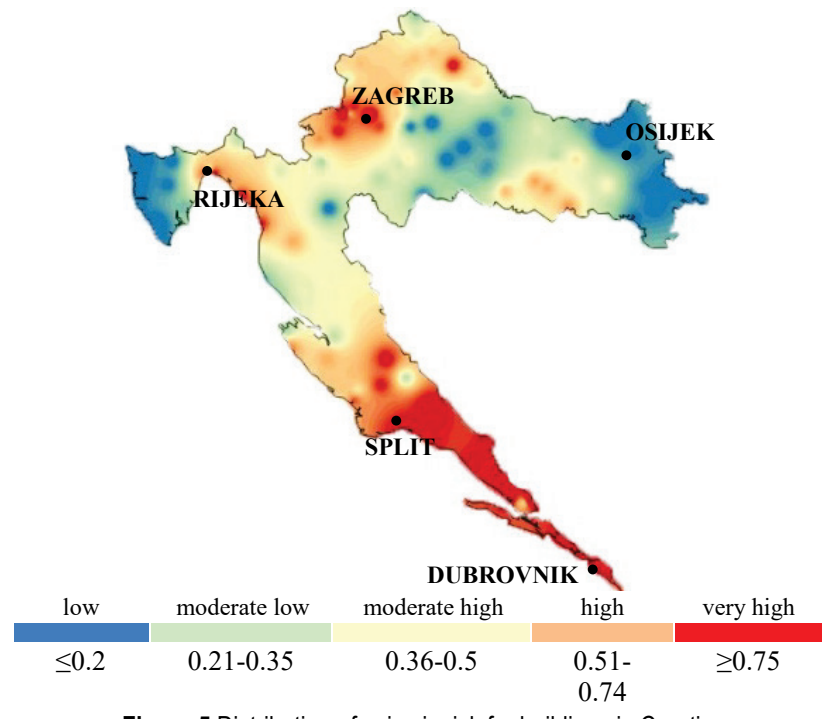

Figure 5 Distribution of seismic risk for buildings in Croatia

An expected earthquake excitation for capital city was defined according to Seismic hazard map for Croatia (Fig. 2). The hazard factor was obtained from Fig. 4, and then after multiplication with $V_{\text {build }}$ relative potential risks were calculated in terms of risks for buildings according to their construction age.

The values of seismic risk for buildings are evaluated according to seismic hazard map for Croatia and expected peak ground acceleration $(g)$ for a given location.
Fig. 5 shows that the eastern and western localities in Croatia have the least critical situation, from the point of view of physical seismic risk, because the risk indicator is negligible. Values of very high risk index, in addition to capital city of Zagreb, have the localities in the south of Croatia, on the Adriatic coast like Dubrovnik.

\subsection{Determination of Prediction Model}

In order to present the majority of the results for the most vulnerable cities, the prediction model for certain building's vulnerability level was developed according to the results for 429 municipalities and 127 cities in Croatia. Six vulnerability levels for buildings were derived from 0.5 to 1.0 (in increment of 0.1) (Fig. 6).

Every vulnerability level is then related to peak ground acceleration distribution.

32 cities are localized on the prediction model based on their current expected PGA according to Figure 2 and calculated vulnerability level.

The prediction model gives an indicative outcome after possible earthquake event expressed in terms of percentage of threatened buildings.

An example of the application will be presented for capital city of Zagreb. According to the seismic hazard map for Croatia, the expected peak ground acceleration for Zagreb is $0.26 g$. For this $P G A$ value, it is anticipated that $90.2 \%$ of buildings will be threatened. In the situation that an earthquake strikes with $P G A$ of $0.1 g$ or $0.2 g$, the percent of threatened buildings will be $7 \%$ and $68 \%$ respectively. Another advantage of this prediction model is the relation between different cities corresponding to the same vulnerability curve with the intention that those cities have a similar age distribution of buildings.

Every curve is one vulnerability level, where 1.0 is the highest and presents the most vulnerable cities according to their buildings age distribution. On the other hand, vertical lines present the seismic levels based on the peak ground acceleration values. The most vulnerable cities according to the possible seismic event based on the Hazard map are those, which expect the ground acceleration equal or greater than $0.25 \mathrm{~g}$. Although, the city 
of Opuzen is in the last section of vulnerability level based on its seismicity it is not the most vulnerable or threatened city because of its building vulnerability level $(76 \%$ of buildings built after 1980).

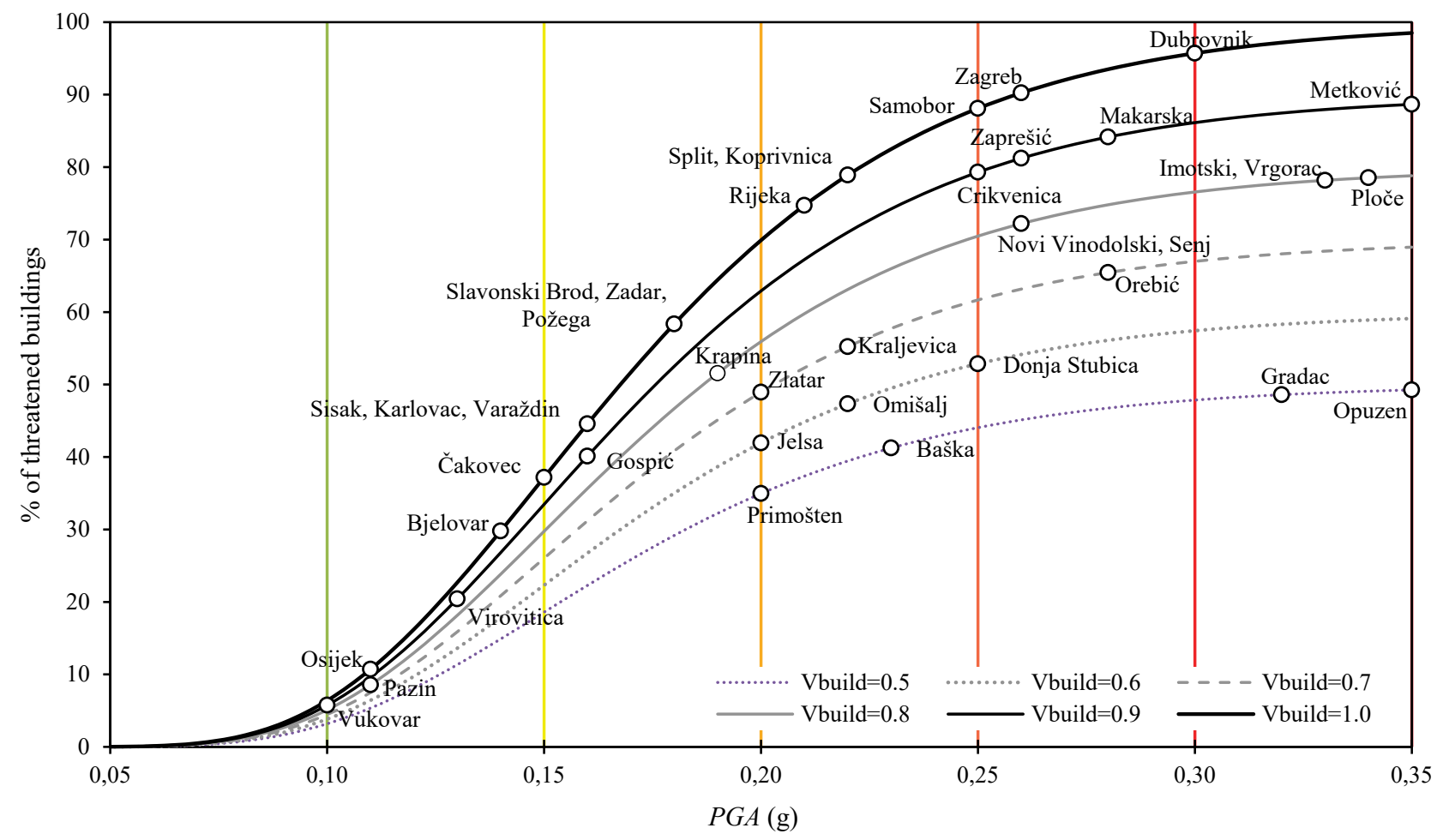

Figure 6 The prediction model for threatened buildings in Croatia in function of PGA

\section{CONCLUSIONS}

The absence of institutional and community organization, weak preparedness for emergency response, political instability and the lack of economic health in a certain geographical area can contribute to the increase of risk. Therefore, the potential negative consequences are not only related to the impact of the hazardous event as such, but also to the capacity to absorb the impact and the control of its implications in a given geographical area.

For Croatia, as an earthquake prone country, the concept of rapid seismic risk assessment was applied in order to allocate corresponding vulnerability indicators to Croatian cities to signify which of them are the most vulnerable to possible earthquake events.

In order to obtain effective and suitable indicators for risk assessment, building vulnerability based on construction age was examined and evaluated.

The primary objective of this study was to propose the prediction model in terms of direct importance measures of risks examined by relative physical variable (building) in relation to the probability of a seismic event. This model emphasizes which cities and what areas in Croatia must be taken seriously in terms of risk and where detailed risk analysis is indispensable. It should be pointed out that the resulting seismic risk is suitable for management purposes, like organisation of emergency civil services, investment decisions and possible building retrofitting.

The methodology of deriving prediction model can be applicable to other countries.

\section{REFERENCES}

[1] Işik, E. (2016). Consistency of the rapid assessment method for reinforced concrete buildings. Earthquakes and Structures, 11(5), 873-885. https://doi.org/10.12989/eas.2016.11.5.873

[2] Işık, E. (2015). Investigation of an Existing RC Building with Different Rapid Assessment Methods. BitlisEren University, Journal of Science and Technology, 5, 71-74. https://doi.org/10.17678/beujst.42802

[3] Hadzima-Nyarko, M., Pavić, G., \& Lešić, M. (2016). Seismic vulnerability of old confined masonry buildings in Osijek, Croatia. Earthquakes and Structures, 11(4), 629-648. https://doi.org/10.12989/eas.2016.11.4.629

[4] Coburn, A. \& Spence, R. (2002). Earthquake Protection. Second Edition, John Wiley \& Sons, Chichester. https://doi.org/10.1002/0470855185

[5] Procjena ugroženosti Republike Hrvatske od prirodnih i tehničko-tehnoloških katastrofa i velikih nesreća. Državna uprava za zaštitu i spašavanje, Zagreb, 2013.

[6] Croatian bureau of statistics, 2011, http://www.dzs.hr/ default_e.htm

[7] Lantada, N., Irizarry, J., Barbat, A. H., Goula, X., Roca, A., Susagna, T., \& Pujades, L. G. (2010). Seismic hazard and risk scenarios for Barcelona, Spain, using the Risk-UE Vulnerability Index Method. Bulletin of Earthquake Engineering, 8, 201-229. https://doi.org/10.1007/s10518-009-9148-z

[8] Eleftheriadou, A. K., Baltzopoulou, A. D., \& Karabinis, A. I. (2014) Seismic Risk Assessment of Buildings in the Extended Urban Region of Athens and Comparison with the Repair Cost. Open Journal of Earthquake Research, 3, 115134. https://doi.org/10.4236/ojer.2014.33012

[9] Abo El Ezz, A., Nollet, M.-J., \& Nastev, M. (2016). Assessment of earthquake-induced damage in Quebec city, Canada. International Journal of Disaster Risk Reduction, 12, 16-24. https://doi.org/10.1016/j.jjdr.2014.11.004 
[10] Tamima, U. \& Chouinard, L. (2016). Development of evacuation models for moderate seismic zones: A case study of Montreal. International Journal of Disaster Risk Reduction, 16, 167-179. https://doi.org/10.1016/j.ijdrr.2016.02.003

[11] Makhoul, N., Navarro, C., Lee, J., Abi-Youness, A. (2016). Assessment of seismic damage to buildings in resilient Byblos City. International Journal of Disaster Risk Reduction, 18, 12-22. https://doi.org/10.1016/j.jidrr.2016.05.007

[12] Preciado, A., Ramirez-Gaytan, A., Salido-Ruiz, R. A., CaroBecerra, J. L., \& Lujan-Godinez, R. (2015). Earthquake risk assessment methods of unreinforced masonry structures: Hazard and vulnerability. Earthquakes and Structures, 9(4), 719-733. https://doi.org/10.12989/eas.2015.9.4.719

[13] Eleftheriadou, A. K. \& Karabinis, A. I. (2013). Evaluation of damage probability matrices from observational seismic damage data. Earthquakes and Structures, 4(3), 299-324. https://doi.org/10.12989/eas.2013.4.3.299

[14] Martinez-Cuevas, S. \& Gaspar-Escribano, J. M. (2016). Reassessment of intensity estimates from vulnerability and damage distributions: the 2011 Lorca earthquake. Bulletin of Earthquake Engineering, 14, 2679-2703. https://doi.org/10.1007/s10518-016-9913-8

[15] Apostolska, R., Necevska-Cvetanovska, G., Bojadjiev, J. \& Bojadjieva, J. (2016). Seismic performance of RC high-rise buildings - a case study of 44 storey structure in Skopje (Macedonia). Tehnički vjesnik, 23 (4), 1177-1183. https://doi.org/10.17559/TV-20150312110020

[16] Ademović, N. \& Hrasnica, M. (2015). Capacity degradation and crack pattern development in a multi-storey unreinforced masonry building. Građevinar, 67 (04.), 351-361. https://doi.org/10.14256/JCE.1191.2014

[17] Chaulagain, H., Rodrigues, H., Spacone, E., \& Varum, H. (2015). Seismic response of current RC buildings in Kathmandu Valley. Structural Engineering and Mechanics, 53(4), 791-818 https://doi.org/10.12989/sem.2015.53.4.791

[18] Sarhosis, V., Asteris, P. G., Mohebkhah, A., Xiao, J., \& Wang, T. (2016). Three dimensional modelling of ancient colonnade structural systems subjected to harmonic and seismic loading. Structural Engineering and Mechanics, 60(4), 633-653. https://doi.org/10.12989/sem.2016.60.4.633

[19] Demir, A., Nohutcu, H., Ercan, E., Hokelekli, E., Altintas, G. (2016). Effect of model calibration on seismic behaviour of a historical mosque. Structural Engineering and Mechanics, 60(5), 749-760. https://doi.org/10.12989/sem.2016.60.5.749

[20] Palanci, M., Kalkan, A., \& Senel, S. M. (2016). Investigation of shear effects on the capacity and demand estimation of RC buildings. Structural Engineering and Mechanics, 60(6), 1021-1038. https://doi.org/10.12989/sem.2016.60.6.1021

[21] Kalman-Šipoš, T. \& Hadzima-Nyarko, M. (2017). Rapid Seismic Risk Assessment. International Journal of Disaster Risk Reduction, 24, 348-360. https://doi.org/10.1016/j.ijdrr.2017.06.025

[22] HRN EN 1998-1:2011. Projektiranje potresne otpornosti konstrukcija - 1. dio: Opća pravila, potresna djelovanja i pravila za zgrade. Eurorcode 8: Design of structures for earthquake resistance. Part 1: General rules, seismic actions and rules for buildings, 2011.

[23] Herak, M. (2012). Croatian map of seismic hazards. Proceedings of the I $V^{\text {th }}$ Conference of Croatian platform for disaster risk reduction / Zagreb, 4-12.

[24] Salgado-Gálvez, M. A., Cardona, O. D., Carreño, M. L., \& Barbat, A. H. (2015). Probabilistic seismic hazard and risk assessment in Spain. Monography CIMNE IS69, International Center for Numerical Methods in Engineering.
[25] Sigmund, Z., Radujković, M., \& Lazarević, D. (2016). Decision support model for seismic strengthening technology selection of masonry buildings. Technical Gazzete, 23(3), 791-800. https://doi.org/10.17559/TV-20151208142529

[26] Pravilnik o tehničkim normativima za izgradnju objekata visokogradnje u seizmičkim područjima, Službeni list SFRJ br. 31, Beograd, 1981.

[27] Tehnički propis za betonske konstrukcije (NN 101/05).

[28] Tehnički propis za betonske konstrukcije (NN 139/2009).

[29] King, S. A., Kiremidjian, A., Pachakis, D., \& Sarabandi, P. (2004). Application of empirical fragility functions from recent earthquakes. Proceedings of the $13^{\text {th }}$ World Conference on Earthquake Engineering, Canadian Association for Earthquake Engineering / Vancouver, Canada.

[30] Barzilai, J. (1997). Deriving weights from pairwise comparison matrices. Journal of the Operational Research Society, 48(12), 1226-1232.

\section{Contact information:}

doc. dr. sc. Tanja KALMAN ŠIPOŠ, dipl. ing. građ.

Josip Juraj Strossmayer University of Osijek

Faculty of Civil Engineering

Vladimira Preloga 3, 31000 Osijek, Croatia

E-mail: tkalman@gfos.hr

izv. prof. dr. sc. Marijana HADZIMA-NYARKO, dipl. ing. građ.

Josip Juraj Strossmayer University of Osijek

Faculty of Civil Engineering

Vladimira Preloga 3, 31000 Osijek, Croatia

E-mail:mhadzima@gfos.hr 